\title{
THE RELATIONSHIP BETWEEN CONDITION FACTOR AND MEAT YIELD OF WILD OYSTER CRASSOSTREA CUCULL ATA BORN
}

\author{
by \\ SAM WOUTHUYZEN ${ }^{1}$ ) and ATJEP SUWARTANA ${ }^{1}$ )
}

ABSTRACT

From April 1982 to October 1982, 393 specimens of oyster were collected near mangrove roots from Piru, Waisala, Wailale, Pelita Jaya (Seram Island) Ihamahu (Saparua Island), and Manipa Island for sondition factor analysis. The regression of meat yield $(\mathrm{Y})$ on whole meat weight $\left(\mathrm{X}_{1}\right)$ and condition factor $\left(\mathrm{X}_{2}\right)$ could be expressed by the following equation: $\mathrm{Y}=0.062 X_{1}+0.127 \mathrm{X}_{2}-10.975$. The analysis of correlation indicated that the meat yield of oyster depends on the condition factor. Hydrologieal parameters which affected the condition factor are described.

\section{ABSTRAK}

Dari bulan April sampai dengan Oktober 1982, sejumlah 393 ekor tiram telah dikumpulkan dan dianalisa faktor kondisinya dari beberapa hutan bakau di Firu, Waisala, Wailale, Pelita Jaya (Pulau Seram), Ihamahu (Pulau Saparua), dan Pulau Manipa. Hasil regresi kandungan daging $(\mathrm{Y})$ terhadap seluruh berat daging $\left(\mathrm{X}_{1}\right)$ dan faktor kondisi $\left(\mathrm{X}_{2}\right)$ dapat dinyatakan dalam persamaan: $\mathrm{Y}=0,062 \mathrm{X}_{1}+$ $0,127 \mathrm{X}_{2}-10,975$. Analisa korelasi menunjukkan bahwa kandungan daging tiram tergantung pada faktor kondisi. Parameter hidrologis yang mempengaruhi faktor kondisi dibicarakan.

\section{INTRODUCTION}

The condition faktor is usually used to describe the degree of fatness of an oyster or the extent to which an oyster fills the shell cavity. The changes of the degree of fatness of oyster from time to time determine both the meat yield and taste.

The appearance of the oyster which is related to its condition, is an important factor in consumer acceptance. Oysters in prime condition have a good appearance with a smooth cream-coloured, rounded body and with thick, crinkly, creamy mantles. A fat oyster (high in condition factor) is a glycogen rich oyster, its meat nearly fills the shell cavity and this produces a high meat yield. A fat oyster also has the rich taste

${ }_{1}^{1}$ Ambon .Research Station, National Institute of Oceanology, Ambon, Indonesia, 
of fat so this may affect future sales. Conversely, thin, transparent, flabby mantles, or a body blotched or dark in colour or with dark digestive gland indicates an oyster in poor condition (QUAYLE 1969, MEDCOF 1961).

In Indonesian waters, there are six species of oysters namely, Crassostrea cuculata, Saccrostrea echinata, Aletrynella plicatula, Hyotissa sp. cf. hyotis, Ostrea sp. cf. follium and Ostrea cristagalli (KASTORO 1978). From the six species only C. cucullata and S. echinata, which are dominant, have potential for culture and are distributed throughout the Indonesian waters. These species are commonly called "rock oyster" or "mangrove oyster", because it lives attached to mangrove roots, stones, and mollusc shells.

In some areas, such as Marunda, Jakarta Bay, people have harvested these oysters for commercial purposes. But they do not know when is the best time for harvesting to get high yield and good quality meat, and therefore high financial return. To answer this question, the growers or farmers must know the fatness cycle or condition factor of the oyster.

A quantitative measure of condition factor permits the growers to analyse accurately variation in productivity of their grounds and gives an indication whether or not they are utilizing all parts of their oyster farms to the best advantage (QUAYLE 1969). The present paper will discuss the relationship between condition factor and meat yield.

\section{MATERIAL AND METHODS}

All specimens were collected from April 1982 to October 1982 from Piru, Wailale, Waisala, Pelita Jaya (Seram Island), Ihamahu (Saparua Island) and Manipa Island (Figure 1). Length, width, thickness, wet meat weight, dry meat weight and the volume of shell cavity were measured.

Dry meat weight was measured by weighing the meat after specific draining time (15 minutes) in a drying oven held at $95-98^{\circ} \mathrm{C}$ until the weight remained constant. The volume of shell cavity was measured by the displacement method.

The condition factor is generally obtained from formula Volume of shell cavity (ml)

Condition factor = ---------------------- x 1000

For high quality meat the condition factor usually ranges from $100-150$, medium quality meat between $80-100$ and poor quality meat below 80 (MEDCOF 1961). 
THE RELATIONSHIP BETWEEN CONDITION FACTOR

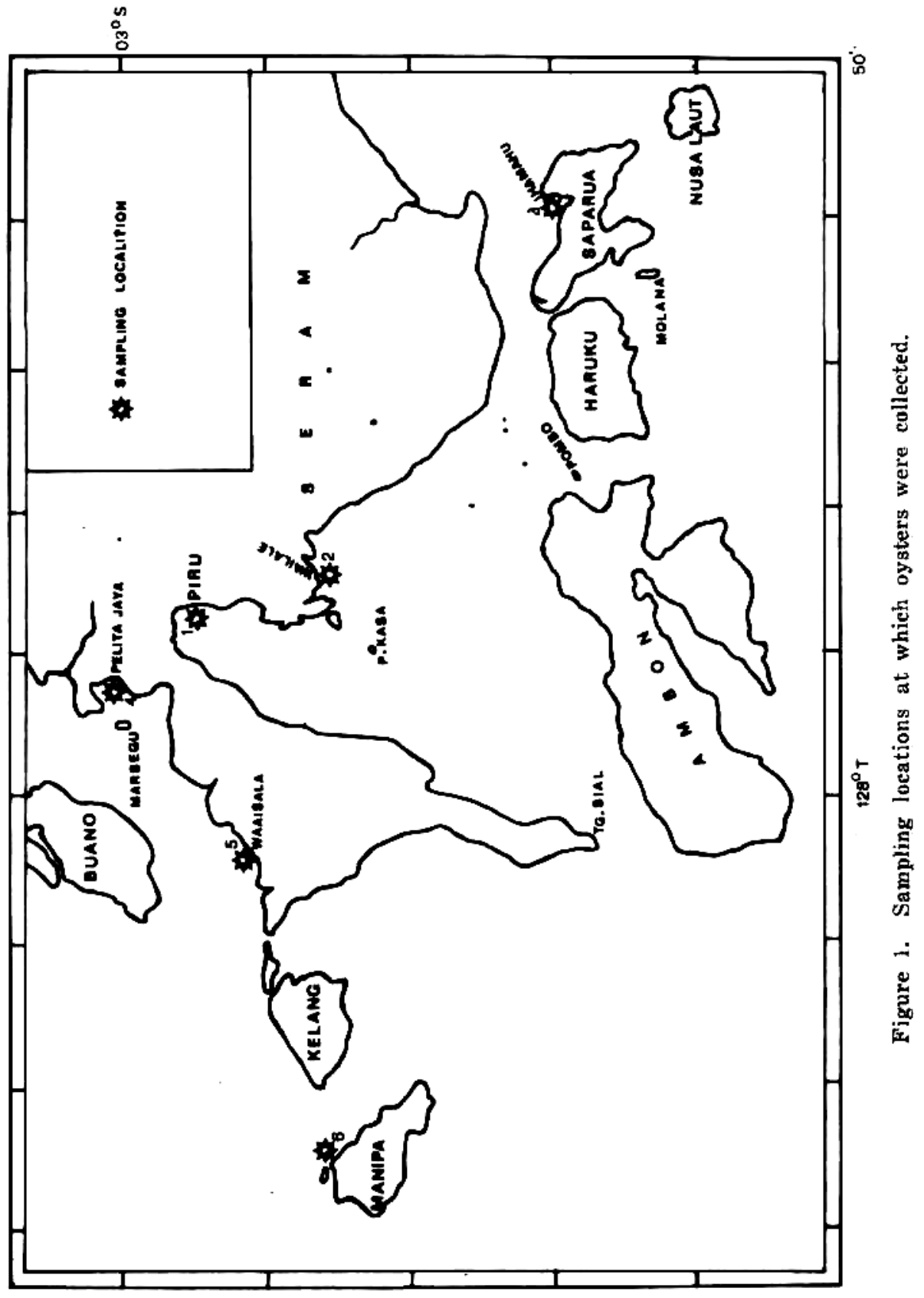


The meat yield (wet meat yield) can be estimated by multiple linear regression: $Y-a+b_{1} X_{1}+b_{2} X_{2}$; where $Y$ is the meat yield, $X_{1}$ is the whole (total) weight of the oyster, $X_{2}$ is the condition factor and $a, b_{1}$, and $b_{2}$ are the constants (BAZIGOS 1974). For the regression analysis, only 166 were randomly chosen out of the total sample of 393 specimens.

\section{RESULTS}

The 393 specimens collected ranged in length from about $7.4 \mathrm{~cm}$ to $17.3 \mathrm{~cm}$ with an average of $12.2 \mathrm{~cm}$. The whole weight ranged from $62 \mathrm{~g}$ to $411 \mathrm{~g}$, averaging $169 \mathrm{~g}$. The meat yield ranged from $3.3 \mathrm{~g}$ to $42.1 \mathrm{~g}$, averaging $9.6 \mathrm{~g}$ and condition factor ranged from 27 to 165 with an average of 80 .

The average condition factor and hydrological parameters at each location and in each month are given in Table 1. The raw data of whole

Table 1. Average condition factor of oyster Crassostrea cucullatu, and hydrological parameters of each month and in each localion.

\begin{tabular}{|c|c|c|c|c|c|c|}
\hline Month & Location & $\mathrm{N}$ & $\begin{array}{l}\text { Cond. Fac. } \\
\text { (unit) }\end{array}$ & Sal. & Temp. & Rem.* \\
\hline April '8-2 & $\begin{array}{l}\text { Wailale } \\
\text { Piru }\end{array}$ & $\begin{array}{l}31 ! \\
15\end{array}$ & $\begin{array}{l}68 \\
86\end{array}$ & $\begin{array}{l}35.00 \\
30.13\end{array}$ & $\begin{array}{l}20.68 \\
26.50\end{array}$ & $\begin{array}{l}\text { p.q } \\
\text { m.q }\end{array}$ \\
\hline May/June & $\begin{array}{l}\text { Wailale } \\
\text { Piru } \\
\text { Ihamahu }\end{array}$ & $\begin{array}{l}31 \\
11 \\
31\end{array}$ & $\begin{array}{l}71 \\
84 \\
77\end{array}$ & $\begin{array}{l}34.14 \\
30.00 \\
34.85\end{array}$ & $\begin{array}{l}27.52 \\
26.28 \\
27.15\end{array}$ & $\begin{array}{l}\text { p-q } \\
\text { m.q } \\
\text { p.q }\end{array}$ \\
\hline July & $\begin{array}{l}\text { Wailale } \\
\text { Piru } \\
\text { Ihamahu }\end{array}$ & $\begin{array}{l}24 \\
10 \\
25\end{array}$ & $\begin{array}{r}73 \\
109 \\
72\end{array}$ & $\begin{array}{l}35.37 \\
33.68 \\
35.00\end{array}$ & $\begin{array}{l}26.10 \\
26.47 \\
26.37\end{array}$ & $\begin{array}{l}\text { p.q } \\
\text { h.q } \\
\text { p.q }\end{array}$ \\
\hline August & Wailale & 30 & 78 & 33.82 & 25.50 & p.q \\
\hline September & $\begin{array}{l}\text { Wailale } \\
\text { Pelita Jaya } \\
\text { Ihamahu }\end{array}$ & $\begin{array}{l}30 \\
25 \\
30\end{array}$ & $\begin{array}{r}74 \\
104 \\
69\end{array}$ & $\begin{array}{l}33.86 \\
34.66 \\
34.67\end{array}$ & $\begin{array}{l}28.94 \\
26.12 \\
26.37\end{array}$ & $\begin{array}{l}\text { p.q } \\
\text { h.q } \\
\text { p.q }\end{array}$ \\
\hline October & $\begin{array}{l}\text { Wailale } \\
\text { Pelita Jaya } \\
\text { Waisala } \\
\text { Manipa }\end{array}$ & $\begin{array}{l}30 \\
27 \\
16 \\
27\end{array}$ & $\begin{array}{l}67 \\
97 \\
98 \\
63\end{array}$ & $\begin{array}{l}34.54 \\
21.83 \\
33.48 \\
34.71\end{array}$ & $\begin{array}{l}26.11 \\
26.14 \\
26.80 \\
26.70\end{array}$ & $\begin{array}{l}\text { p.q } \\
\text { m.q } \\
\text { m.q } \\
\text { p.q }\end{array}$ \\
\hline
\end{tabular}

\footnotetext{
* Remarks:

p.q is poor quality meat,

m.q is medium quality meat,

h.q is high quality meat.
} 
weight of meat $\left(\mathrm{X}_{1}\right)$, condition factor $\left(\mathrm{X}_{2}\right)$ and weight of meat yield $\left(\mathrm{X}_{3}\right)$ of each individual oyster are presented in Table 2.

The estimate of meat yield by multiple linear regression was expressed in the following equation: $\mathrm{Y}=0.062 \mathrm{X}_{1}+0.127 \mathrm{X}_{2}-10.975$.

The multiple correlation coeficient, $\mathrm{R}^{2}=0.797$, $(\mathrm{R}=0.893)$. The critical value was 0.198 (d.f. $=163$; $\mathrm{P}<0.01$. The two variable linear correlation coeficients are summarized in Table 2 and figured in Figure 2. From Table 2 and Figure 3, the relationship between meat yield (Y) and whole weight $\left(\mathrm{X}_{1}\right)$, and between meat yield $(\mathrm{Y})$ and condition factor $\left(\mathrm{X}_{2}\right)$ are highly correlated, whereas the relationship between whole weight $\left(\mathrm{X}_{1}\right)$ and condition factor $\left(\mathrm{X}_{2}\right)$ is weak. This means that, although the whole weight of oyster was high, the condition factor could be either high or low.

From multiple linear regression equation we find that with an increase of one gram in whole weight of oyster $\left(X_{1}\right)$ gives only an increase of 0.062 grams meat yield $(Y)$ but with an increase of each unit in condition factor $\left(\mathrm{X}_{2}\right)$ there is an average increase of 0.127 grams in meat yield weight. It seems that the increase in one unit of condition factor $\left(\mathrm{X}_{2}\right)$ makes the increase of meat yield about two times, compared with the increase of one gram of whole weight $\left(X_{1}\right)$. Thus the high or low meat yield of oyster greatly depends on condition factor.

Table 2. The two variable correlation coefficients.

\begin{tabular}{rll}
\hline${ }^{\mathrm{r}} \mathbf{Y} . \mathbf{X}_{1}=$ & $\mathbf{0 . 7 0 1 * *})$ & (highly significant) \\
- & $\left.{ }^{\mathrm{r}} \mathbf{Y} . \mathbf{X}_{2}=\quad \mathbf{0 . 4 9 T}^{* *}\right)$ & (highly significant) \\
${ }^{\mathrm{r}} \mathbf{X}_{\mathrm{r}} \mathbf{X}_{2}=-0.077$ & (not significant) \\
\hline
\end{tabular}

critical values with 163 d.f. $=0.151(\mathrm{P}<0.05)$

$$
=0.198(\mathrm{P}<0.01)
$$

\section{DISCUSSION}

From the multiple linear regression analysis, we found that the yield of oyster meat was greatly influenced by the condition factor. The condition factor itself was influenced by some environmental factors.

Table 1 shows that temperatures in all locations ranged from $25.50{ }^{\circ} \mathrm{C}$ to $28.94^{\circ} \mathrm{C}$. Apparently there is no specific correlation pattern between temperature and condition factor. Thus, perhaps temperature is not the main factor influencing the condition factor. In temperate region, 
conversely, temperature has an important role in changing the condition factor. When the temperature is low (winter season), the metabolism of oyster is low too, causing the oyster accumulate glycogen and this resulting in high meat quality. When temperature increases (summer season), the oyster becomes more active or the oyster spawns, this causing the glycogen in the meat decreases and resulting in lower meat quality (MEDCOF 1961).

According to QUAYLE (1980), the changes of condition factors in tropical water may be affected by sharp changes in salinity. If the salinity of the water is high, the shell growth tends to be rapid at the expense of meat growth (KASTORO, personal communication). So the low condition factor of oysters in Wailale, Ihamahu and Manipa Island (see Table 1) may be due to the high salinity in these locations. The salinity at low tide and at high tide were almost the same, 33.68\% and 34.60\% respectively. In Pelita Jaya, Piru and Waisala the condition factors of oyster were medium to high. The salinity ranges in these locations were wide (because there are rivers at both locations). The salinity at low tide was $21.83 \%$ and at high tide was $34.60 \%$. Thus, salinity seems to have a great effect on condition factor.

An important influence on the condition factor also is the abundance of phytoplankton (food). There is a relation between seasonal variation of the fattening of oyster with both the species and the quantity of food. The probable cause of fattening is vigour feeding on diatoms, particularly on Skeletonema costatum. When the quantity of S. costatum in the water is high, the oyster fattens most rapidly. Conversely, during the season when $S$. costatum is scarce or absent, the oysters are so lean and poor in quality as to be unmarketable (CHAN 1950).

\section{CONCLUSIONS}

1. The analysis of multiple linear regression was expressed by the equation: $\mathrm{Y}=0.062 \mathrm{X}_{1}+0.127 \mathrm{X}_{2}-10.975$, The multiple corre lation coeficients and the two variable correlation coeficients, except the correlation between $\mathrm{X}_{1}$ and $\mathrm{X}_{2}$ are highly correlated Thus, the meat yield are highly dependent on the condition factor.

2. The two main possible factors which greatly affected the condition factor were salinity and the abundance of food (phytoplankton). Further investigation is required, particulary on the effects of food on condition factor. 
THE RELATIONSHIP BETWEEN CONDITION FACTOR
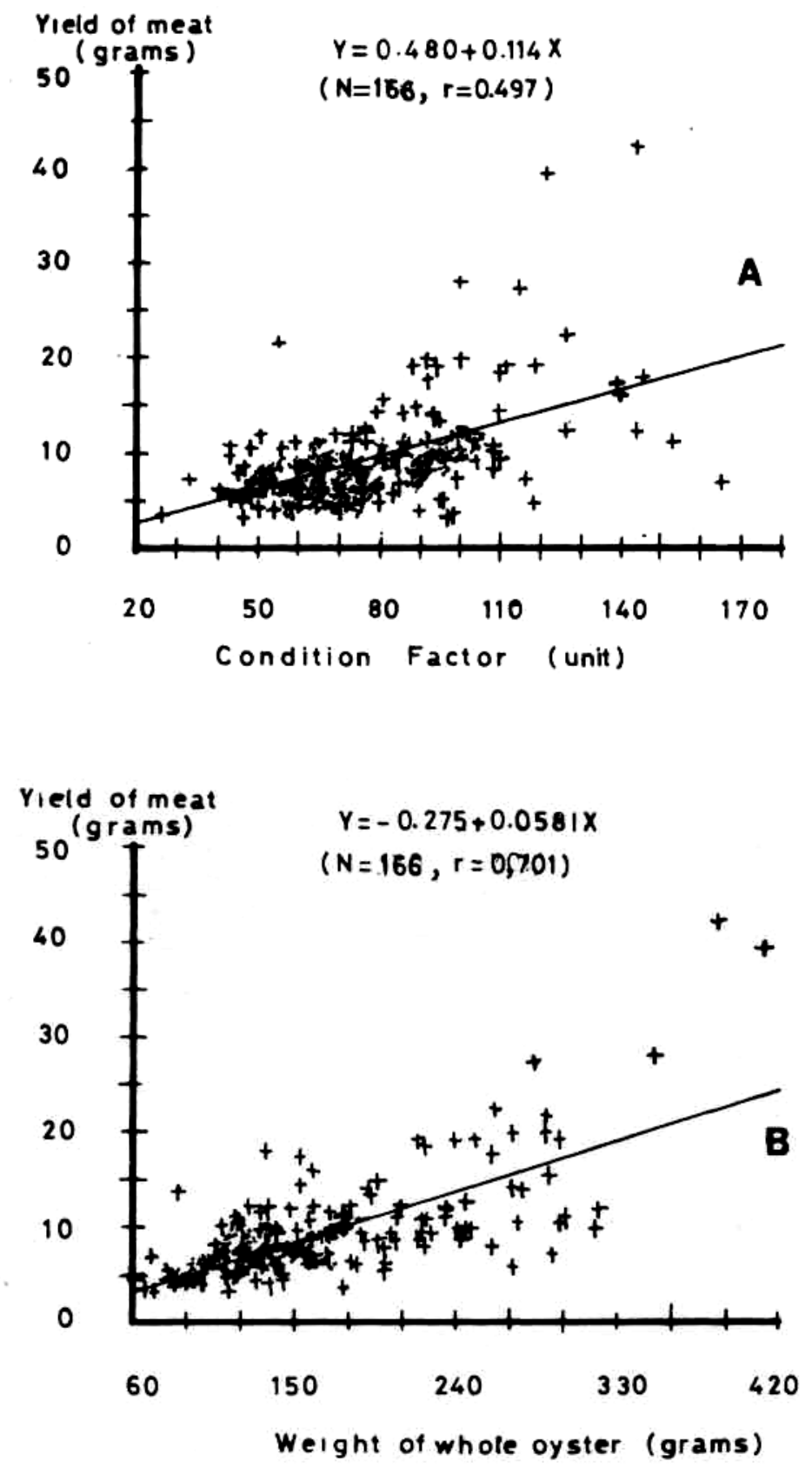

Figure 2A. The relationship between yield of meat and condition factor.

Figure 2B. The relationship between yield of meat and weight of whole oyster. 


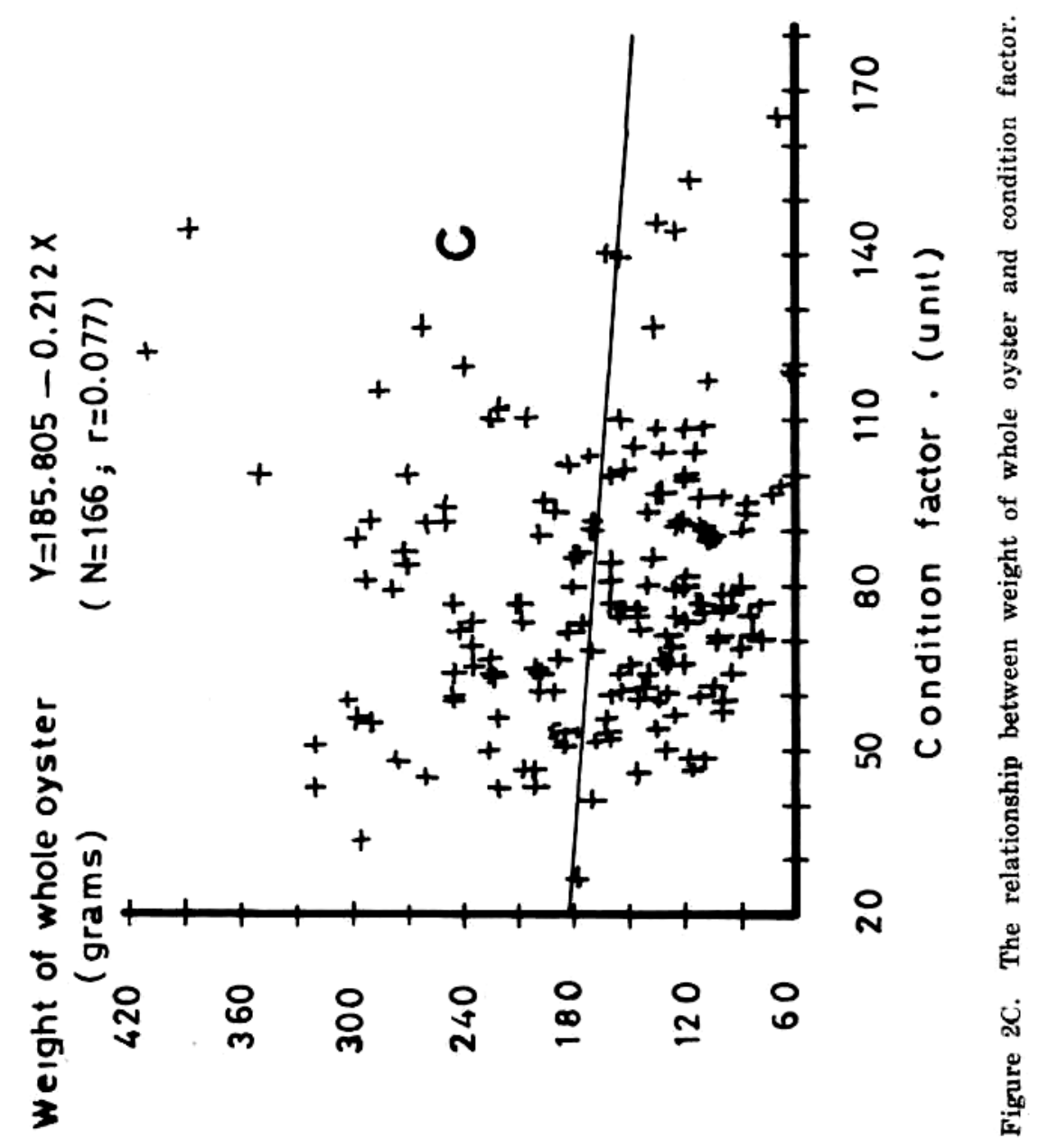




\section{THE RELATIONSHIP BETWEEN CONDITION FACTOR}

3. The condition factor is important in term of production. However, oyster farmer must continue to produce oysters and cannot avoid seasonal fluctuation in condition factor. Thus, it is necessary to examine the beds carefully and take advantage of areas that produce oysters with a high condition factor, not only the average throughout the year, but at a specific time.

\section{ACKNOWLEDGEMENT}

I would like to express my thanks to Dr. K. ROMIMOHTARTO and Mr. CHARLES ANGEL for their valuable correction of the manuscript and also to all colleagues for their good cooperations in obtaining the data. Thanks are forwarded to Mr. F. LAETEMIA and his colleagues for their technical assistance.

\section{REFERENCES}

Bazigos, G.P. 1974. Applied fisheries statistic. FAO FISH, Pap., 135: 64 p.

CAHN, A.R. 1950. Oyster culture in Japan. U.S. Dep. Of the Interior Fish and Wildlife Serv. Fish. Leaflet Washington D.C. 80 pp.

KASTORO, W. 1978. Beberapa catatan biologi tiram untuk menunjang usaha budidaya. Simposium modernisasi perikanan rakyat. Jakarta, 27-30 Juni 1978. 13 pp.

MedCof, J.C. 1961. Oyster farming in the maritimes. Fish. Res. Board of Canada Bull, 131: 158 pp.

Quayle, D.B. 1969. Pasific oyster culture in British Colombia. Fish. Res. Board of Canada Bull. 160: 193 pp.

QuAYLE, D.B. 1980. Tropical oyster culture and methods. International Development Research Center. Ottawa, Ont., IDRC, 1980. 80 pp. 